\title{
THE IMPORTANCE OF USING CERTIFIED SEED
}

\author{
Sandra Bogdanović ${ }^{* 1}$, Velimir Mladenov², Svetlana Balešević Tubić ${ }^{3}$
}

\begin{abstract}
Summary
Certified seed is produced from the seed of known genetic origin and genetic purity with controlled and tested production, processed and declared in accordance with the Law on Seeds. Production of certified seed is carried out under the supervision of the Ministry of Agriculture and Environmental Protection, by seed producers formally listed in the Seed Register. Seed is processed in registered seed processing centres and quality is tested in laboratories accredited for seed testing. The organization authorized by the Ministry of Agriculture and Environmental Protection issues labels for packaging of certified seed. The utilization of the genetic potential of varieties for quality and yield is achieved using certified seed. High quality seed is a prerequisite for farmers seeking to achieve higher yields, and therefore higher profits.
\end{abstract}

Key words: certified seed, farm saved seed, quality.

\section{Introduction}

There are only few countries in the world making full use of certified seed. The Republic of Croatia is an example of a country where the use of certified seed was $100 \%$ prior to EU accession. In Republic of Serbia, on the other hand, at least $50 \%$ of all seed used for sowing wheat is undeclared seed or "farm saved seed". Likewise, about $40-50 \%$ of soybean crops are based on "farm saved seed". It is mainly in central and southern parts of Serbia, where wheat is grown on small fragmented areas and consumed raw for animal feed, that farmers traditionally use their own seed for at least three years. In order to reduce this percentage, farmers must be educated on the dangers of using uncertified seed (Mladenov, 2011). Worldwide, the percentage of certified seed use ranges from $20 \%$ (in developing countries) to $80 \%$ (in developed countries) (Table 1).

In Czech Republic use of "farm saved seed" is around 30\% of total production (Table 2)

Stručni rad (Professional paper)

1 Bogdanović S*., Seed Association of Serbia, Bulevar Oslodođenja 69/1, 21000 Novi Sad, Serbia,

2 Mladenov V., University of Novi Sad, Faculty of Agriculture, Novi Sad, Trg Dositeja Obradovića 8, Serbia

3 Balešević Tubić S., Institute of Field and Vegetable Crops, Maksima Gorkog 30, Novi Sad, Serbia.

*e-mail: office@semenarska.rs 
Table 1: Use of "farm saved seed" for various crop varieties across the EU (ESA-SCP data), Table 1: Upotreba „semena sa tavana“ za različite gajene vrste širom EU (ESA-SCP podaci)

\begin{tabular}{lccccc}
\hline Crop & & $\begin{array}{c}\text { Coceral 2012 } \\
(\mathrm{mha})\end{array}$ & $\begin{array}{c}\text { ESA Survey } 2012 \\
(\mathrm{mha})\end{array}$ & FSS\% 2005 & FSS\% 2012 \\
\hline Wheat & soft & 23,0 & 19,4 & 49 & 55 \\
& durum & 2,7 & 2,2 & 10 & 39 \\
Barley & winter & 4,5 & 4,0 & 42 & 46 \\
& spring & 7,8 & 7,4 & 56 & 55 \\
Rye & & 2,4 & 2,4 & 77 & 73 \\
Oats & 2,7 & 2,2 & 71 & 70 \\
Triticale & 2,7 & 2,6 & 59 & 70 \\
Total & & 47,0 & 40,2 & 52 & 56 \\
\hline
\end{tabular}

Table 2: Statistical overview of the use of "farm saved seed" in the Czech Republic (2010-2014,), (FSS in Czech Republic, ESA Annual Meeting 2014)

Table 2: Statisticki prikaz upotrebe "semena sa tavana” u Češkoj Republici (2010-2014), (FSS in Czech Republic, ESA Annual Meeting 2014)

\begin{tabular}{lccc}
\hline \multicolumn{1}{c}{ Average 2011-2014 } & $\begin{array}{c}\text { Total surface area } \\
\text { (ha) }\end{array}$ & $\begin{array}{c}\text { Farm saved seed } \\
\text { (ha) }\end{array}$ & $\%$ \\
\hline Winter wheat & 783276 & 217984 & 27,8 \\
Winter barley & 265066 & 48241 & 18,2 \\
Spring barley & 103642 & 27924 & 26,3 \\
\hline
\end{tabular}

Certified seed is produced from seed of known genetic origin and genetic purity, produced in a controlled and tested manner, processed and declared in accordance with the Law on Seeds. Seed quality is ensured through a lengthy production process that begins by establishing the seed crop varietal seeds, crop nurture and expert testing of crops, and ends after harvesting, processing, quality control and labelling. As such, each country strives to ensure good organization of seed production regulations that govern all stages in the seed production process (Milošević et al. 1996). Production of certified seed is carried out under the supervision of the Ministry of Agriculture and Environmental Protection, via producers who are formally listed in the Seed
Register. Processing of this seed is carried out at registered processing facilities, while quality testing is conducted at laboratories accredited for seed testing. Labels for packaging certified seed are issued by the organization authorized by the Ministry of Agriculture and Environmental Protection. Under the provisions of the Law on Seeds (Art. 19), seed can only be placed on the market if it has been processed. According to the same law, seed categories are: 1 . pre-basic; 2. basic 3. first generation certified seed; 4 . second generation certified seed; 5. production seed (Official Gazette No.45/05). Besides being the carrier of genetic potential for the development of plants and the obtaining of high yields, seed can also hold different diseases and the insects that feed on them (Milošević and Malešević, 2004). 
"Only by sowing seed of certified genetic potential of varieties can we reach their full fruition, which is the goal of any agricultural producer."

\section{Advantages of using certified seed}

Farmers who use certified seed receive higher quality seeds as a prerequisite for achieving higher yields (10-30\%). The use of certified seed prevents the spread of weed species via seed, thereby reducing the number of treatments required with herbicides while reducing costs. Many diseases of cultivated plants are transferred via seed, which is why it is important to use seeds with the required health and specific purity. Only seeds processed and treated at registered processing facilities are able to meet the prerequisites required for a healthy and bountiful crop. Seed processed at registered centres is at considerably higher level in terms of uniformity of seed size and seed quality than the seed saved by farmers from their own production. By treating seed at processing centres with fungicides and insecticides, in order to protect the seed from pests and diseases, a higher quality disbursement of particle preparations on the seed itself is ensured.

\section{Damage resulting from the use of uncertified seed:}

1) Prolonged use of uncertified seed leads to a decline in fertility. Physical seed blending leads to the mixing of seeds of different varieties. This mixing most often occurs during harvest, transport, storage and processing. A decline in fertility may also occur due to the crossing of different varieties of small grains. There is a much greater danger of mutual crossing in cross-pollinated species (rye and triticale) than in self-pollinated species (wheat, barley, oats and soybeans).
2) Uncertified seed is often infected with warehouse insects and diseases, given that they are most often kept in inadequate storage facilities.

3) The quality of certified seed is tested in accredited laboratories and is always better than the quality of uncertified seed. Certified seed has higher germination and fewer impurities than uncertified seed, due to the method of selection and seed treatment with protective devices during processing. Farmers often process seed inappropriately, resulting in a failure to achieve good quality seed processing equivalent to those achieved at processing centres equipped with the latest equipment. Uncertified seed contains more weeds, broken seeds, empty shells, small and diseased seed than certified seed. Farmers do not possess the required equipment for quality application of fungicides and insecticides to seed, so their attempts result in uneven distribution of seed treatments. Seed that is not treated evenly and properly with the seed treatment substance will suffer from more diseases and insect attacks. Likewise, seed that is over treated will have lower germination.

4) The highest quality fungicides, insecticides and damping agents are not available in free circulation and, as such, uncertified seed is protected with lower quality pesticides. Moreover, polymers are very rarely used by farmers, which means the reduced quality of uncertified seed. A polymer improves the adhesion of protective agents for seed, thereby improving their effect. A seed with polymer glides more easily during sowing and thus the seed can be sown more precisely. Polymers contribute by providing much better protection for workers involved in processing and sowing from the harmful effects of pesticides used to protect seeds. Polymers also prevent the emission of pesticides into the 
environment.

5) The quality of uncertified seed is unknown because this seed is not tested at accredited laboratories. As a result, farmers sow at a rate determined in their head, which leads to sowing more or less seed than the recommended amount. They most often sow more seed than necessary. The effect of this practice is lodging crops, the emergence of disease, greater loss in harvests and lower yields, and therefore lower profits.

As a result of all of the aforementioned deficiencies, certified seed gives a higher yield than uncertified seed. Yield reductions most commonly total around $5 \%$, but can be as high as $10-30 \%$.

\section{Conclusion}

The use of certified seed should be encouraged, particularly self-pollinating plants, where the use of farm saved seed is most common (wheat, soy). In order to achieve this goal, it is necessary to stimulate the use certified seed among farmers and educate them on all the advantages of using certified seed. Until awareness is raised among farmers on the use of certified seed, use of such seed will not increase. The damage caused by using uncertified seed would be reduced if regulations were passed allowing farmers to use seeds from their own production, though under the condition that production, harvest, storage and processing is carried out in a professional manner (Agrawal, 1980). It would be mandatory for such seed to be tested at an accredited laboratory. This practice already exists in Western Europe, where farmers can, under the aforementioned conditions, use their own seed for planting, which is referred to as “farm saved seed". FSS can be used, according to EU regulations, for personal own use on a surface area of up to 10 ha.

In order to reduce the use of "farm saved seed”, breeders should protect their varieties. Protected varieties may not be used for further reproduction without paying compensation. Agricultural producers, with the exception of small farmers (up to 10 ha), are obliged to pay compensation for holders of breeders' rights, in line with market conditions for the use of "farm saved seed". If a variety is protected at the level of an individual country, that varietal protection is only valid within that country. As such, those varieties should be protected by the Community Plant Variety Office (CPVO), after which protection is valid in all $28 \mathrm{EU}$ Member States. The CPVO is an institution for the enforcement of the protection of varieties within the EU, but non-EU members can also apply (Balešević-Tubic, 2011).

\section{References}

Agrawal RL (1980): Seed technology, Oxford \& IBH Publishing Company, 685-690.

Balešević-Tubić S, (2011): Zakonska regulativa. Proizvodnja semena u Republici Srbiji. Semenarska Asocijacija Srbije, Novi Sad: 19 - 35.

Milošević M, Malešević M (2004): Semenarstvo. Institut za ratarstvo i povrtarstvo, Novi Sad.

Milošević M, Mihaljev I, Ćirović M, Dokić P (1996): Opšte semenarstvo, Naučni institut za ratarstvo i povrtarstvo, Novi Sad.

Mladenov V, Milošević M (2011): Uticaj sorte i lokaliteta na kvalitet semena ozime pšenice, Selekcija i semenarstvo, 17(1): 83-95.

Pinstrup-Andersen P, de Londono M, Infante M. (2009): A Suggested Procedure for Estimating Yield and Production Losses in Crops, PANS 22(3): 359-366. 


\title{
ZNAČAJ UPOTREBE DEKLARISANOG SEMENA
}

\author{
Sandra Bogdanović, Velimir Mladenov, Svetlana Balešević Tubić
}

\begin{abstract}
Izvod
Sertifikovano seme se proizvodi od semena poznatog genetičkog porekla i genetičke čistoće čija je proizvodnja kontrolisana i koje je ispitano, dorađeno i deklarisano u skladu sa Zakonom o semenu. Proizvodnja sertifikovanog semena vrši se pod nadzorom Ministarstva poljoprivrede i zaštite životne sredine, kod proizvođača koji su upisani u Registar proizvođača semena. Dorada ovakvog semena vrši se u Registrovanim doradnim centrima, a ispitivanje kvaliteta u akreditovanim laboratorijama za ispitivanje semena. Etikete za pakovanje sertifikovanog semena izdaje ovlašćena organizacija od strane Ministarstva poljoprivrede i zaštite životne sredine. Upotrebom sertifikovanog semena postiže se iskorišćenje genetskog potencijala sorte za kvalitet i prinos. Kvalitetniji semenski materijal za poljoprivredne proizvođače predstavlja preduslov za postizanje većih prinosa, a samim tim i profita. Upotrebom sertifikovanog semena sprečava se širenja korovskih biljaka putem semena, a samim tim smanjuje se broj tretmana herbicidima uz smanjenje troškova. Mnoge bolesti gajenih biljaka prenose se semenom stoga je važno koristiti seme koje je odgovarajućeg zdravstvenog stanja i određene čistoće. Samo seme dorađeno i tretirano u registrovanim doradnim centrima, može da zadovolji ove preduslove za zdrav i prinosan usev. Dorađeno seme u registrovanim doradnim centrima je na znatno višem nivou po ujednačenosti krupnoće i kvaliteta semena nego seme koje ostavljaju farmeri od sopstvene proizvodnje. Tretiranjem semena, fungicidima i insekticidima u cilju zaštite semena od bolesti i štetočina, u doradnim centrima, obezbeđuje se kvalitetniji raspored čestica preparata na samom semenu. U Republici Srbiji od ukupno utrošene količine semena za setvu pšenice, minimum $50 \%$ je nedeklarisano seme odnosno „seme sa tavana“. Isto tako, oko 40 - 50\% površina pod sojom zasnovano je „semenom sa tavana“. Kako bi se ovaj procenat smanjio neophodna je edukacija farmera o štetnosti upotrebe nedeklarisanog semena.
\end{abstract}

Ključne reči: sertifikovano seme, seme sa tavana, kvalitet.

Primljen:3.11.2015.

Prihvaćen: 25.12.2015. 